\title{
A ordem no olho da rua: uma experiência ética e estética no Rio de Janeiro
}

\author{
Carla dos Santos e Silva Oliveira ${ }^{\mathrm{i}}$
}

\begin{abstract}
RESUMO
O presente artigo pretende reunir algumas produções artísticas pensadas a partir da prática de se mover pelas ruas do Rio de Janeiro, com o intuito de estabelecer alguns diálogos entre autores das duas primeiras décadas dos séculos XX e XXI. Debruçando-me sobre essas obras, meu objetivo é refletir como as transformações experimentadas pela metrópole aparecem nas referidas quadras de tempo, bem como discutir a presença da questão do ordenamento urbano, tão premente na Belle Époque carioca e ainda manifesta nos dias de hoje. Para além de um determinado eixo temático, finalmente, proponho-me a identificar a insistência de alguns atributos nos trabalhos que brotam da fruição dos espaços públicos, como a irreverência, o espanto e o afeto, entendendo a experiência do cotidiano na rua como uma oportunidade invulgar de proximidade.
\end{abstract}

Palavras-chave: Rua; Ordenamento; Modernidade; Contemporaneidade.

\begin{abstract}
This article seeks to gather some artistic productions conceived through the artistic practice of roaming the streets of Rio de Janeiro to establish links between authors belonging to the first two decades of the 20th and 21st centuries. As I carefully examine these works, I aspire to reflect on how the transformations the metropolis experienced emerge in the works within the established period, as well as discussing the presence of issues about urban development, so conspicuous during Rio's Belle Époque that still echo in our present time. Going beyond a fixed guiding theme, at last, I propose to identify the persistence of certain attributes in works that stem from the enjoyment of public spaces, such as irreverence, astonishment, and affection, understanding the experience of day-today street life as a unique opportunity for closeness.
\end{abstract}

Keywords: Street; Development; Modernity; contemporaneity.

\section{INTRODUÇÃO}

\footnotetext{
${ }^{\mathrm{i}}$ Mestranda na área de Estudos Literários, com especialidade em Literatura Brasileira, na Universidade do Estado do Rio de Janeiro (UERJ).

E-mail: oliv_carla@hotmail.com
} 
Sobre os Escritos Corsários, Paulo Roberto Pires (2020) relembra que, para Pier Paolo Pasolini, o lugar do intelectual era na rua, "no olho do furacão, no cruzamento radical entre vida, obra e militância", ideia que, segundo o crítico, "é pura abstração entre os gados de diversas extrações que ruminam, sossegados, no vasto e verdejante pasto chamado Brasil" (PIRES, 2020). Ao ler esse texto, fui transportada para a introdução de Modernismo no Rio de Janeiro: Turunas e Quixotes, livro em que Mônica Velloso (2015) relata a origem de seu interesse no grupo de intelectuais e humoristas da boêmia carioca: o encontro com artigos, charges e caricaturas do grupo Verde-amarelo, segmento conservador do movimento modernista de São Paulo, cujo discurso recaía sobre o menoscabo do Rio de Janeiro (VELLOSO, 2015, p. 24).

Nesse sem-número de publicações, na quadra de tempo entre as décadas de 1910 e 1920, as desqualificações guardam justificativas sortidas: cientificistas, o clima tropical que seria nocivo à ordem política e intelectual; econômicos, a cultura perdulária e a entropia crônica frustrariam o êxito financeiro; e culturais, o samba, a praia e o Carnaval se converteriam em elementos desarticuladores das energias produtivas (VELLOSO, 2015, p. 24). Tal atributo expansivo supostamente não coadunaria com o tino administrativo necessário à metrópole, na visão do referido grupo: a vocação para a irreverência, que pode se relacionar diretamente a uma disposição para a sociabilidade, não se associava de forma nenhuma aos preceitos de ordem, concluindo-se, dessa forma, que o Rio de Janeiro estaria descredenciado para exercer a função de capital da República.

Data desse período o estabelecimento de alguns clichês, uma vez que humoristas da revista carioca $D$. Quixote trocavam provocações com o grupo de Plínio Salgado, do jornal Correio Paulistano, estabelecendo uma oposição entre o ethos empreendedor de seus vizinhos e certa cultura marginal ${ }^{1}$. Pode-se dizer que é a partir desse conflito que o humor se torna um atributo medular nessa modernidade da Guanabara, na medida que os intelectuais do Rio acusavam seus opositores de rigidez, formalidade e provincianismo excessivos. Não à toa, mais tarde, em 1934, Noel Rosa compõe "Feitiço da Vila"2, cuja letra marca a posição dessas hegemonias culturais, também aludindo à política do café com leite: "São Paulo dá café, Minas dá leite e a Vila Isabel dá samba” (VELLOSO, 2015, p. 26) $)^{3}$. 
As ruas cariocas encarnavam esse "espectro da desordem" (CARVALHO, 1994, apud Ibidem, p. 43): a cidade passava por uma intensa remodelação arquitetônica, europeizando-se; a então recente abolição da escravatura lançou à própria sorte uma expressiva massa de trabalhadores, também preterida pelo mercado que privilegiava imigrantes; e a política sanitarista implementada suscitava críticas. Dessa maneira, o contexto social fez com que a consolidação do Rio como metrópole moderna fosse um processo composto por imbricações, em que se viam tensionados esforços urbanizadores e extratos populares, aos quais uma boa parte da intelectualidade se via identificada.

Essa considerável parcela de artistas também se posicionava à margem daquela incipiente República, denegando a imagem de uma metrópole que se edificava aos moldes franceses. Tal circunstância fez com que rebentassem das ruas, pelas mãos de inúmeros cronistas, chargistas, compositores etc., trabalhos em que esses questionamentos se faziam patentes. E, nesse ponto, encontra-se o cerne do que o presente trabalho ambiciona esboçar, exemplificando alguns desses textos escritos na Belle Époque carioca, espelhando-os com trabalhos contemporâneos, tendo em vista que, como há um século, também se vivencia uma revolução tecnológica, um momento de debilidade na política global, além de uma catástrofe sanitária.

Nesse contexto, nas proposições aqui reunidas, irrompem gestos congêneres: derivando do desejo de se mover pelas ruas, pululam questões como a do ordenamento, que se coloca como um ponto primordial em todas as cidades desse continente que se fez país à força bruta e que parece apartar as pessoas umas das outras por meio de critérios no mínimo duvidosos. Tal aspecto salienta o descomedimento dos regimes reguladores perpetrados sobre parte da população, que alastram violências e injustiças, antes praticadas em nome de um determinado projeto de Nação e hoje reiteradas sobre o cadáver desse empreendimento, mediante à apoteose da necropolítica neoliberal.

Ademais, são trabalhos que, nas primeiras duas décadas do século XX e do XXI, diante de tempos embrutecidos, pretendem-se fabuladores de saídas possíveis, buscando, a partir da experiência concreta do espaço público, a produção de sentidos, seja através da irreverência, do espanto, da ternura, mas, impreterivelmente, pela via da proximidade. São textos, músicas, performances, poemas que se põem a inventariar o mínimo no fluxo cotidiano - tudo o que foge à sanha homogeneizadora -, tramando restaurar o prazer da vida na rua, sonhando (ou retomando?) outros modos de convívio e de conivência. 
Foi a poeta francesa Jeanne Catulle-Mendès a responsável pela internacionalização do epíteto "Cidade Maravilhosa”, quando, em 1913, publicou o livro La Ville Merveilleuse (SIMAS, 2019, p. 146). O emblema, enfim, cuidava de amalgamar o paraíso perdido retratado nos textos do século XVI à instância que se erigia à imagem e semelhança de Paris: fundiam-se a obra divina e a glória da criação humana. A alcunha se fixa, porém, apenas com a gravação da marchinha de André Filho para o Carnaval de 1935, que vira uma espécie de hino da metrópole, mas uma ode dessacralizada, ou como descreveu Renato Gomes, urdida na "sacralização descontraída da alegria" (GOMES, 1994, p. 103).

No entanto, as esquinas teimavam em oferecer obscenidades que corrompiam o idílio dos entusiastas do progresso. Um exemplo dessa afirmação se encontra em Bambambã!, de 1923, de Orestes Barbosa - que corrobora o princípio desordeiro apontado pelos intelectuais paulistas (e que se expressava, literal e inversamente, nas ruas) - em que o compositor se debruça sobre uma Casa de Detenção e sobre a cidade, lançando mão do topos do duplo e escancarando as desigualdades sociais reproduzidas nesses espaços. Como em "Nomes de favela" , canção em que Paulo César Pinheiro se lamenta de que "Prazer se acabou lá no Morro dos Prazeres/ E a vida é um inferno na Cidade de Deus", no texto "O vendedor de jornais", o jornalista lastima que a cidade fabrique uma lógica invertida ao dístico da bandeira brasileira, tendo "o prodígio de ser ao contrário do que proclamamos e do que deveríamos ser" (BARBOSA, 1993, p. 93).

\footnotetext{
Tudo é às avessas.

Rua da Saúde.

O estrangeiro vai atrás da placa, aluga uma casa lá e morre.

Mas, se a rua é pestilenta, por que tem esse nome?

Ninguém explica.

Assim, a rua da Harmonia com os seus assassinatos bissemanais - a Ladeira do Livramento, onde ninguém escapa de um assalto a mão armada.

E na política, como na diplomacia, na administração, como na arte, é tudo ao contrário do que se anuncia (BARBOSA, 1993, p. 94).
}

A crônica narra um ato de violência cometido por um membro da guarda civil contra um menino, o "vendedor de jornais" do título, de aproximadamente seis anos de 
idade. A criança fora punida por brincar com uma carrapeta achada na rua. A guarda, recém-criada sob o governo de Rodrigues Alves, conforme denuncia Barbosa, teria sido uma instituição concebida para atender aos "pistolões" da época. O agressor, portanto, era um agente "civilizador" pronto a aplicar a ordem à rua; o cronista, por sua vez, atua como guardião das gentes que não se conformam aos moldes que lhes eram impelidos.

A linguagem é inovadora, a começar pelo título Bambambã!, onomatopeia que espoca nas calçadas, evocando a conhecida gíria que nomeia aquele que detém um saber: o "bamba". Aí se percebe, como Walter Benjamin e João do Rio afiam ${ }^{5}$ as ruas, nomeadoras das coisas, como criadoras de um mundo. A escrita segue esse mesmo princípio arrojado e inventivo. As frases são curtas. Os parágrafos são abruptamente cortados, como flashes de luz, em que essa constelação de personagens, dos mais diversos possíveis, brilha.

A ideia de constelação aparece oportunamente, aliás, no prefácio da obra, referindo-se à famosa canção de Barbosa, "Chão de estrelas", e ratificando a aproximação entre as camadas populares e os intelectuais, já mencionada acima. $\mathrm{O}$ grupo do qual o jornalista fazia parte incluía desde expoentes da cultura do Rio, como Mário Lago, Francisco Alves, Agripino Grieco, e representantes de outros espectros da sociedade carioca, como Zé Pretinho, o italiano Kid-Pepe e o português Germano Augusto (BARBOSA, 1993, p. 9).

Barbosa compõe um mural onde esses desviantes, não aclimatados à "nova sintaxe urbana" (BARBOSA, 1993, p. 12), podem fruir livremente, como “Alice Cavalo de pau”, a cafetina de mente prodigiosa que escrevia para o periódico Rio $\mathrm{Nu}$, pertencente a Olavo Bilac e Arthur Azevedo; ou como a poeta apenada Maria Nair, "a musa da sarjeta": "É lírica. Conhece os versos de Olegário Mariano. Recita 'As duas sombras' para as outras, que ficam espantadas. Sabe que existe também o Souza Cruz, [...]. Confunde os poetas com os cigarros." (BARBOSA, 1993, p. 56).

Não obstante, a despeito do que a crônica supracitada sugere, é cabível defender a existência de um ordenamento outro: as ruas, no Carnaval, eram chamadas de "repúblicas", cada uma possuindo seus cordões, bandas, coretos e grupos de foliões (VELLOSO, 2015, p. 46). E não só na festa: "nos cortiços, entrudos, Festa da Penha, capoeira e terreiros" (Ibidem, p. 44), notava-se que eram partilhados sistemas de valores 
próprios, ideia defendida até mesmo por Barbosa (1993), quando, em seus textos, o cronista desvelava a lógica singular do malandro, como em "A origem da malandragem":

O malandro - o homem que vive misteriosamente, trabalhando a seu modo, porque malandro quer dizer esperto, sabido, e não ocioso como erradamente se supõe, sai da figura interessante do garoto de rua, de calças de suspensório de tira de pano - moleques vendedores de bala, soltadores de papagaios e tascadores de balão a cujo bando alegre eu pertenci (BARBOSA, 1993, p. 103).

Se o malandro era o senhor dos becos e vielas, a cidade se traduzia em um campo de disputa, onde se justapunham e se digladiavam "duas redes distintas: a física, marcada pela multiplicidade e pela fragmentação, e a simbólica, que impunha a si a tarefa das razões ordenadoras" (VELLOSO, 2015, p. 11). Um exemplo desse embate entre a iconografia imposta e a materialidade da rua pode ser notado na crônica de Olavo Bilac, na Revista Kosmos, em 1906, sobre a Festa da Penha, que, como outros costumes tradicionais, tentava-se expurgar do fabuloso boulevard, a Avenida Central (com grifos meus):

É que esses carros e carroções, enfeitados com colchas de chita, puxados por muares ajaezados de festões, cheios de gente ébria e vociferante, passeando pela cidade a sua escandalosa bruega; esses bandos de romeiros cambaleantes, com o chapéu esmagado ao peso das moscas, o peito cheio de medalhas de papel, e beijando a efígie da Nossa Senhora da Penha com os beiços besuntados de zurrapa; esse alarido, esse tropel de povo desregrado; todo esse espetáculo de desvairada e bruta desordem ainda se podia compreender no velho Rio de Janeiro de ruas tortas, de betesgas escuras, de becos sórdidos. Mas no Rio de Janeiro de hoje, o espetáculo choca e revolta como um disparate... Num dos últimos domingos, vi passar pela Avenida Central um carroção atulhado de romeiros da Penha: naquele amplo Boulevard esplêndido, sobre o asfalto polido, entre as fachadas ricas dos prédios altos, entre as carruagens e os automóveis que desfilam [...] me deu a impressão de um monstruoso anacronismo: era a ressurreição da barbárie, - era a cidade selvagem que voltava, como uma alma do outro mundo, vindo perturbar e envergonhar a vida da idade civilizada... (DIMAS, 2006, p. 370 apud MEDEIROS, 2014, p. 7).

Como explicita o trecho, a adesão de Bilac ao plano modernizador de Pereira Passos é eufórica e ávida em expulsar da cena esse componente da memória tradicional, cedendo o protagonismo ao dito progresso. Todavia, esparramada pelas ruas, estruturavase uma "cidadania paralela", como atesta a coluna do Jornal do Brasil "Queixas do povo", "em que as camadas populares expressavam suas demandas e desacordos. Frequentemente essas queixas partem dos moradores de uma determinada rua, sugerindo- 
se a possibilidade de uma organização da vizinhança" (SILVA, 1988 apud VELLOSO, 2015, p. 46).

O referido evento religioso também estava dentro desse ordenamento alternativo, pois era lá que se reuniam os músicos da Pequena África (dos bairros Saúde, Gamboa e Cidade Nova), sendo este um dos primeiros palcos dos artistas que revolucionariam a música brasileira, a despeito da repressão policial. Os inúmeros sambas sobre a Penha comprovam o vigor da celebração, como o samba "Festa da Penha"6, de Cartola e Adalberto de Souza: "Levarei dinheiro pra comprar/ Velas de cera/ Quero levar flores/ Para a santa padroeira/ Só não subirei/ A escadaria ajoelhado/ Pra não estragar/ O terno que foi emprestado."

Sobre esse movimento de repulsão de tudo que não estava de acordo com os ideais positivistas, há que se enfatizar que a instauração da modernidade se desenrolou apartada da racionalidade unificadora do mercado. A Nova República no Rio de Janeiro não atravessou a era pré-industrial, tendo aproximadamente $50 \%$ da população envolvida em toda a sorte de profissões informais ou tarefas domésticas, figurando entre esses trabalhadores biscateiros, camelôs e diaristas (VELLOSO, 2015, p. 44). Vale recuperar, também, que a taxa de pessoas que não possuíam letramento, em senso realizado em 1890, era de $82,6 \%$ (SCHWARCZ, 2017, p. 24).

Em A Alma encantadora das ruas, de 1908, João do Rio reúne um pequeno inventário das profissões desempenhadas nas calçadas, escritos que já havia publicado anteriormente, a exemplo do que havia elaborado, também dedicando-se às religiões ${ }^{7}$, na Gazeta, em 1904, influenciado pelo francês Henri Antoine Jules-Bois, que publicou Les petites religions de Paris (ANTELO in RIO, 1997, p. 14). Afinal, se o projeto urbanístico era importado da França, a "Cidade das Letras" não passaria incólume: tal como Baudelaire, Toulouse-Lautrec, entre outros, boa parte dos artistas brasileiros voltaram sua atenção para o bas-fond (VELLOSO, 2015, p. 45). O referido jornalista foi um deles, subordinado ao establishment, operava como um genuíno "espião do capitalismo", ou melhor, como uma espécie de agente dúplice:

o autor, travestido de flâneur, entrega-se ao mercado não sem revelar um aspecto social inovador da atividade janeleira: o de comportar-se como se a rigor soubesse que o valor de sua mercadoria é apenas uma identificação passageira com o valor de troca, já que, nesse particular, revela-se um virtuose ao exibir, despudorado, sua própria venalidade (ANTELO in RIO, 1997, p. 21). 
Renato Gomes elucida essa possível contradição: "se as ruas são perecíveis como os homens" (RIO, 1997, p. 83), seu desejo é prender ao texto o que está a ponto de ser destruído pela tempestade do progresso, em um gesto de "compulsivo memorialismo", como chamou Flora Süssekind, no texto "O cronista \& o secreto amador" sobre Jacques Pedreira (GOMES, 1994, p. 147 apud SÜSSEKIND in RIO, 1992, p. 26) ${ }^{9}$. Desse modo, os registros abarcam tudo aquilo que é rejeitado pelo modelo de conduta e urbanidade estabelecido: por isso, sua definição de flanar, incluía "meter-se nas rodas da populaça, admirar o menino da gaitinha ali à esquina, [...] conversar com os cantores de modinha das alfurjas da Saúde [...]” (RIO, 1997, p. 50-51).

Na seção "O que se vê nas ruas" do já mencionado livro, na introdução chamada "Pequenas profissões", o cronista afirma que estas eram "produto da miséria ligada às fábricas importantes, aos adelos, ao baixo comércio"; e diz ainda que "o Rio, como todas as grandes cidades, esmiúça no próprio monturo a vida dos desgraçados" (RIO, 1997, p. 90). Nas crônicas que seguem, o autor de Vida vertiginosa escreve sobre os tatuadores, os velhos cocheiros, os músicos ambulantes etc., "todos esses pobres seres vivos tristes" que "vivem do cisco, do que cai nas sarjetas" (RIO, 1997, p. 90).

Destacam-se os textos sobre o vendedor de orações, "menino magro, naquela esquina da rua, era um dos insignificantes agentes desse tremendo micróbio da alma" (RIO, 1997, p. 114); e os "urubus", agentes funerários que caçavam pessoas recémfalecidas como tesouros pelas ruas. Repete-se a noção de ordem na desordem, quando João do Rio lamenta a existência de uma "dolorosa academia da miséria":

[...] até nisso há vocações! Os trapeiros, por exemplo, dividem-se em duas especialidades: a dos trapos limpos e a de todos os trapos. Ainda há os cursos suplementares dos apanhadores de papéis, de cavacos e de chumbo (RIO, 1997, p. 91).

Não se pode concluir essa divagação pelas produções artísticas pensadas a partir da rua, realizadas em trânsito, no início do século XX, sem passar por Lima Barreto, que, como atesta sua biógrafa Lilia Schwarcz, mesmo tendo saído pouquíssimas vezes de sua cidade, foi um grande viajante de seu tempo, convertendo-se em uma: 
recolhem, mas também interpelam seu próprio contexto (SCHWARCZ, 2017, p. 164).

Cabe aqui recapitular que, com o afastamento radical estabelecido entre o âmbito político e a intelectualidade carioca, a partir do governo de Floriano Peixoto, entre 1891 e 1894, os artistas trataram de criar seus próprios espaços de atuação (VELLOSO, 2015, p. 57). A "República das Letras", então, urdia-se nos cafés, nas livrarias, nas confeitarias, nos salões, entre outras instâncias, que abrigavam os grupos de jornalistas, chargistas, compositores etc., formadores de suas "coteries literárias" (MACHADO, 1973 apud VELLOSO, 2015, p. 58).

O autor de Clara dos Anjos era um dos integrantes dessas confrarias e um dos grupos dos quais ele fez parte se reunia no Café Papagaio, onde se juntava a outros nomes da boemia carioca. O estabelecimento tinha esse nome por conta da presença de um papagaio chamado Bocage que, em um determinado momento das confraternizações, também ficava ébrio. A ave, famosa por sua linguagem de baixíssimo calão, que incluía pornografia em versinhos indecorosos e palavrões dirigidos aos republicanos donos do poder, segundo relatos, chegou a ser presa pela polícia por ser um bicho revoltoso (SCHWARCZ, 2017, p. 10-129).

Gravitando nesse microcosmo de irreverência e irmandade, Lima Barreto e seus companheiros cultivavam o ambiente ideal para o debate das grandes questões da época, compartilhando suas impressões sobre o destino da cidade. Nessa circunstância, instituise um contraponto entre as atividades realizadas em recintos fechados e os momentos de descontração e criação coletiva na rua.

\footnotetext{
Nós nos reuníamos nesse tempo (1907-1910) no Café Papagaio. Aí pelas três horas, lá estávamos a palestrar, a discutir coisas graves e insolúveis. Como havia entre nós uns quatro amanuenses, o grupo foi chamado 'Esplendor dos Amanuenses', na intenção de mais justamente destacar aquelas horas de felicidade, de liberdade em oposição às de inércia nas secretarias e repartições, quando, acorrentados à galé dos protocolos e registros, remávamos sob o chicote da vida (BARRETO, 1911 apud VELLOSO, 2015, p. 70-71).
}

O personagem Gonzaga de Sá, de Vida e Morte de M. J. Gonzaga de Sá, publicado em 1919, foi gestado nesse caldo de cultura, sendo também um contumaz frequentador desses cafés, onde, com os seus amigos, empenhava-se em desenvolver propostas reformistas, que contemplavam a moda, a literatura e a moral (VELLOSO, 2015, p. 71). A obra é ainda um convite para fruir a cidade, que se apresentava 
multifacetada, contrastando-se ao imaginário elitizado dominante naquele período: Augusto Machado, biógrafo do protagonista, narra as rememorações deste, por meio de seus deslocamentos pela metrópole.

No romance, o leitor é levado a percorrer um caminho dissonante, em que são desprestigiados os bairros aristocráticos à época, Botafogo e Tijuca, para se enfatizar uma percepção contraditória em relação às mudanças implementadas. $\mathrm{O}$ capítulo chamado " $\mathrm{O}$ passeiador", no qual se acompanham as andanças do homem que abusava da "faculdade de locomoção" (BARRETO, 1919, p. 55), explana o apagamento da história da antiga metrópole, causado pelo "bota-baixo" orquestrado por Pereira Passos.

\begin{abstract}
Subia morros, descia ladeiras, devagar sempre, e fumando voluptuosamente, com as mãos atrás das costas, agarrando a bengala. Imaginava ao vê-lo, nesses trejeitos, que, pelo correr do dia lembrava-se do pé para a mão: como estará aquela casa, assim assim, que eu conheci em 1876? E tocava pelas ruas em fora para de novo contemplar um velho telhado, uma sacada e rever nelas fisionomias que já mais não são objeto. Não me enganei. Gonzaga de Sá vivia da saudade da sua infância garrula e da sua mocidade angustiada. Ia em procura de sobrados, das sacadas, dos telhados, para que à vista deles não se lhe morressem de todo na inteligência as várias impressões, noções e conceitos que essas cousas [...] (BARRETO, 1919, p. 55-56).
\end{abstract}

Como no samba maxixado "A Favela vai abaixo"10, em que Sinhô critica a derrubada do Morro da Favela, que foi proposta durante a gestão de Prado Junior na Prefeitura - "Que saudades ao nos lembrarmos das promessas/ que fizemos constantemente na capela/ Pra que Deus nunca deixe de olhar/ por nós da malandragem e pelo morro da Favela/ Vê agora a ingratidão da humanidade/ O poder da flor sumítica, amarela/ quem sem br/ilho vive pela cidade/ impondo o desabrigo ao nosso povo da Favela" -, Barreto relata o processo de desaparecimento do Morro do Castelo:

Um dia faltou à Repartição (contou-me isso mais tarde) para contemplar, ao sol do meio-dia, um casebre do Castelo, visto cinquenta e tantos anos atrás, em hora igual por ocasião, de uma gazeta da aula primária. Pobre Gonzaga! A casa tinha ido abaixo. Que dor! (BARRETO, 1919, p. 56).

Carmem Lúcia Negreiros de Figueiredo, cuja pesquisa abrange, entre outros temas, o olhar para a paisagem a partir da experiência urbana, demonstra, ainda, a inquietação de Lima Barreto com a questão ambiental: em algumas crônicas, há reclamações referentes ao abandono do Jardim Botânico, "o recanto da cidade que 'fala ainda de Dom João VI'” (FIGUEIREDO, 2015, p. 74). A professora afia que, mais do 
que um rompante nostálgico, o escritor mostra "uma sensibilidade atenta à necessidade da preservação, combatendo a destruição de grandes árvores, [...] para dar lugar à especulação imobiliária” (BARRETO, 1956c, p. 162 apud Ibidem). Mesmo sendo um "homem da cidade", o cronista lastima o desleixo dos grandes proprietários para com a natureza, dizendo ser "excessivamente urbana" a "gente abastada", como em "O cedro de Teresópolis", crônica de 1920, em que comenta sobre o Rio de Janeiro:

\begin{abstract}
Antigamente, pelas vistas que ainda se encontram, parece que não era assim. Os ricos gostavam de possuir vastas chácaras, povoadas de laranjeiras, de mangueiras soberbas, de jaqueiras, dessa esquisita fruta-pão que não vejo mais e não sei há quantos anos não a como assada e untada de manteiga. Não eram só essas árvores que a enchiam, mas muitas outras de frutas adorno, como as palmeiras soberbas, tudo isso envolvido por bambuais sombrios e sussurrantes à brisa. Onde estão aqueles extensos tapumes de maricás que se tornam de algodão que mais é neve, em pleno estio? Os subúrbios e arredores do Rio guardam dessas belas coisas roceiras, destroços como recordações (BARRETO, 1920).
\end{abstract}

Além de denunciar a artificialidade da "cenografia" da metrópole, como em $O s$ Bruzundangas - "De uma hora para outra, a antiga cidade desapareceu e outra surgiu como se fosse obtida por uma mutação de teatro [...]" (BARRETO, 1922 apud GOMES, p. 106) -, a literatura do "Triste visionário" abre alas, ainda, para os subúrbios, que, após a queda do regime monárquico, sofrem grandes transformações (SCHWARCZ, 2017, p. 164). Embora pertencessem a universos díspares ${ }^{11}$, é como se, de alguma maneira, Lima Barreto tomasse para si o desígnio do personagem mais famoso de Machado de Assis, Bentinho, de escrever a "História dos subúrbios"12, como observamos, voltando à Vida e morte de M. J. Gonzaga de Sá, nesse relato sobre as ruas dos subúrbios:

O arruamento do subúrbio é delirante. Uma rua começa larga, ampla, reta; vamos-lhe seguindo o alinhamento, satisfeitos, a imaginar os grandes palácios que a bordarão daqui a anos, de repente, estrangula-se, bifurca-se, subdividese de travessas, que se vão perder em muitas outras que se multiplicam e oferecem os mais transtornados aspectos. [...] Tudo isso se embaralha, confunde-se, mistura-se e, bem não se colhe logo como a população vai se irradiando da linha férrea. As épocas se misturam; os anos não são marcados pelas coisas mais duradouras e perceptíveis (BARRETO, 1919, p. 124-125 apud SCHWARCZ, 2017, p. 181).

Em Recordações do escrivão Isaías Caminha, de 1909, uma das práticas do protagonista é o "passeio de pragmática" pelo bairro de Botafogo, que muito o desagradava. O subúrbio, sim, é, para Caminha, o lugar ideal para se passear a esmo, de 
bonde e a pé. E além de alongar a linha do mapa da capital, Lima Barreto insere em seus textos as gentes vistas por ele em suas viagens na segunda classe dos trens. Na crônica “De Cascadura ao Garnier”, de 1922, o jornalista relembra a velha Estrada Real de Santa Cruz: "Embarco em Cascadura. É de manhã. O bonde se enche de moças de todas as cores com os vestuários de todas as cores" (BARRETO, 1922).

Schwarcz enumera a riqueza e a variedade de termos utilizados por Barreto para descrever as pessoas das ruas, que àquela altura tão pouco transitavam nas vielas textuais, com suas muitas nuances de cores: "negros flexíveis", "azeitonados”, "velhas pretas”, "velhos africanos", "caboclos", "morenos fortes", "mestiços", entre muitos outros (SCHWARCZ, p. 10-11). O ficcionista também não deixou de registrar as diversas maneiras as quais essa população periférica inventava para sobreviver, com suas "profissões mais tristes e inopinadas", como comprova Triste fim de Policarpo Quaresma, de 1911:

velhas fabricantes de rendas de bilros, compradores de garrafas vazias, castradores de gatos, cães e galos, mandingueiros, catadores de ervas medicinais, enfim, uma variedade de profissões miseráveis que as nossas pequena e grande burguesias não podem adivinhar (BARRETO, 1915 apud SCHWARCZ, 2017, p. 181).

Se Benjamin assegurou que era no subúrbio que se dava a batalha entre o moderno e o tradicional - era "o estado de sítio da cidade"; e Nicolau Sevcenko sentenciou que era nessa região que estavam a sofisticação e o afastamento da desordem da urbe - "a cidade era a senzala, o subúrbio a casa grande" - (SCHWARCZ, 2017, p. 165), essa dicotomia perde a força em Lima Barreto, que não tinha uma visão idealizada sobre os dois âmbitos $^{13}$. Talvez a ambivalência e o humor - vezes vestido de ironia fina, vezes pura troça -, diante das circunstâncias "estrambóticas" (BARRETO, 1919, p. 57) que se apresentam para os brasileiros, sejam manifestações da tal ordem tão vindicada. A aposta nessa hipótese é corroborada em "Os enterros de Inhaúma”, de 1922:

\footnotetext{
A pobreza da maioria dos habitantes dos subúrbios ainda mantém neles esse costume rural de levar a pé, carregados a braços, os mortos queridos. [...] Vejoos passar e calculo que os condutores daquele viajante para tão longínquas paragens, já andaram alguns quilômetros e vão carregar o amigo morto, ainda durante cerca de uma légua. [...] espreguiço o olhar por sobre o macio tapete verde do capinzal intérmino que se estende na minha frente. Sonhos de vida roceira me vêm; suposições do que aquilo havia sido, ponho-me a fazer. [...] De repente, tilinta um elétrico, buzina um automóvel, chega um caminhão
} 
carregado de caixas de garrafas de cerveja; então, todo bucolismo do local se desfaz (LIMA BARRETO, 1922).

"As ruas encantam a vida na miudeza que ninguém suspeita" (SIMAS, 2020, p. 149), diz Luiz Antonio Simas em cujo livro, O corpo encantado das ruas (2019), as 42 crônicas principiam com “AS RUAS”, alardeando o desejo de atravessar o Rio de Janeiro restituindo alumbramento ao mundo. Tal compromisso começa em $2013^{14}$, com Pedrinhas miudinhas: Ensaios sobre ruas, aldeias e terreiros, em que o historiador brinca de imaginar o encontro de Walter Benjamin e o Caboclo da Pedra Preta: para ele, quando o filósofo alemão propõe escovar a História a contrapelo, em Sobre o conceito da História, de 1940, aproxima-se da entidade das encantarias, que, em seu canto mais famoso, "Pedrinhas de Aruanda", diz que, de todas as pedras da aldeia, "a miudinha é a que nos alumeia" (Idem, 2013, p. 13).

Nessa primeira obra de Simas que coloca a rua em centralidade, vê-se a advertência logo nas primeiras páginas: "Nas histórias que conto, por prazer e ofício, não cabem grandes batalhas, feitos extraordinários, líderes políticos, gênios da humanidade, efemérides da pátria e similares" (Ibidem). O professor, tal como Benjamin, convoca um pensar a historicidade a partir dos resíduos, daquilo que foge à grandiloquência, ressaltando o quão são essenciais as pequenezas do cotidiano. Portanto, não é possível um passeio pela Praça XV "sem lembrar que ali vivem, consagrados na memória das pedras, os marujos que quebraram as chibatas da marinha de guerra do Brasil na revolta de 1910" (Ibidem, p. 36). Não há como ir a um samba e ignorar que:

\footnotetext{
Na materialidade bruta da Pedra do Sal ressoam batuques de primitivos sambas e berram todos os bodes imolados aos deuses que chegaram da África nos porões dos negreiros, acompanhando seu povo. A Pedra do Sal tem um silêncio que grita Laroiê! nas noites.

Cada degrau da escadaria da ermida da Nossa Senhora da Penha, a mais carioca das santinhas, materializa os milagres e a dor - redentora - de milhares de joelhos esfolados em sacrifícios de louvor e graças aos prodígios da Virgem (Ibidem).
}

Esse texto, "Réquiem para o maracanã", evoca um estádio mítico, que insiste apesar da sanha modernizadora que a tudo pasteuriza, onde "Zizinho e Didi bailaram nas quatro linhas" e "um anjo de pernas tortas cirandou um dia" (Ibidem). O Maracanã, assim 
como a Praça XV, a Pedra do Sal e a Igreja da Penha, apresenta-se como contraponto aos "territórios do esquecimento", "do efêmero", sendo "lugares de memória, da permanência", espaços "sacralizados pelos homens em suas geografias de ritos, antecedem sua própria criação e parecem estar aí desde a véspera da primeira manhã do mundo" (Ibidem).

Nesse contexto, reinventa-se a ágora no botequim: se a utopia é morta e valoroso é o presente, tempo em que restam apenas os sonhos de consumo e a idealização de corpos, para o autor, é no tradicional pé sujo que se situa o antagonismo à lógica padronizadora dos costumes globalizados. É na vida compartilhada, no balcão ou na mesa na calçada, espaço para o pensamento e para o delírio, que se rechaça uma existência guiada pelos ritos do mercado e pela busca do corpo-máquina. Apreende-se, ainda, a persistência da questão “ordem versus desordem”, para mim, a ordem da desordem:

O boteco é a casa do mau gosto, do disforme, do arroto, da barriga indecente, da grosseria, do afeto, da gentileza, da proximidade, do debate, da exposição das fraquezas, da dor de corno, da festa do novo amor, da comemoração do gol, do exercício, enfim, de uma forma de cidadania muito particular. É a República de fato dos homens comuns (Ibidem, p. 28).

De volta à obra $O$ corpo encantado das ruas, cuja capa reproduz um saquinho de doces de Cosme e Damião, o texto "Pipas" se vale de uma rua que é o lugar de saberes e brincadeiras. Simas traça uma historiografia fantástica da pipa, que, para ele, foi inventada na China, há três mil anos; por Arquitas de Tarento, amigo de Platão; por hindus; polinésios; fenícios e egípcios - ou seja, diversas civilizações criaram papagaios, ou foram por eles criadas, para que pudessem dançar nos céus. A pipa, que tem mais nomes do que o diabo no Grande Sertão, passou de dispositivo militar para brinquedo, ou, no Oriente, artifício utilizado para atrair uma vida longa e próspera - e sobrevive, na Quinta da Boa vista, no Parque de Madureira, no Aterro do Flamengo etc. São espécies de artimanhas, feitas da mesma matéria esperta dos vira-latas e das plantas que nascem nos muros, e rechaçam o viver verticalizado dos prédios, assassinos dos ventos.

Mirando ainda os artistas da primeira parte do texto, contam-se semelhanças no que se refere ao gesto de se voltar à rua, estabelecendo-se uma linhagem - não tão direta como a que se revela com Simas - de autores que caminham à beira, se nos debruçamos sobre a produção de um grupo de mulheres da poesia contemporânea carioca ${ }^{15}$. No passado, o andar na rua se fazia uma prática entravada à mulher, tanto como uma fonte 
de fruição quanto como um exercício criativo, por convenções sociais que visavam ao controle sexual, conforme Rebecca Solnit explicita em su'A História do caminhar (SOLNIT, 2016, p. 387). Os interditos de hoje, embora não deixem de envolver questões relacionadas a gênero, assimilam as imbricações da vida na cidade regida pelas leis do capitalismo neoliberal. A rua é, ainda, uma reivindicação.

Em "MORO A SETENTA QUILÔMETROS DO MAR"16, poema de Bruna Mitrano, o prazer na urbe é pensado a partir da impossibilidade: "moro a duas horas e meia do mar/ moro a dois ônibus e/ vinte e quatro estações de trem e/ onze estações de metrô/ do mar// moro a tanta preguiça de ir/ até o mar". Depois de enfatizada a lonjura do caminho nas rotas não realizadas, a poeta narra como é restituída a presença da praia: "mas todo dia piso/ nos dois montes de areia/ da calçada do vizinho/ e lembro que// só esquece o mar/ quem mora perto do mar// [...] às vezes é madrugada e durmo/ ouvindo o barulho da água/ do valão de frente a minha casa", trama que diz respeito à sua poesia, forjada nos e dos materiais sujos e ordinários das ruas de seu bairro.

A articuladora cultural, cria de Bangu, marca no poema o distanciamento social compelido a pretos e pobres, afastados da região mais abastada da cidade - "eu não esqueço que// moro onde não escolhi/ moro onde posso morar e/ às vezes é de madrugada e faz silêncio". Defrontamo-nos com situação parecida no samba de Renato da Rocinha de nome "Moro lá"17: "Moro lá/ Depois do final da linha/ Minha casa é quarto, sala, banheiro e cozinha/ Não tem condomínio/ Nem pago aluguel". No entanto, nessa instância, fabula-se um reino, em que, diferentemente dos versos de Bandeira, o sujeito não é amigo da realeza e sim o próprio soberano: "Lá sou negro rei/ Minha nega é rainha".

Os versos finais de Mitrano, "e acordo com a boca salgada/ nos olhos dois montes de areia", parecem saudar o escrito de Lima Barreto que diz "vivo nela [a cidade] e ela vive em mim" (BARRETO Apud GOMES, 1994, p. 156), donde se lê pertencimento e incômodo. Movimento duplo semelhante pode ser encontrado em seu Não (2016), obra que assinala uma série de violências as quais o corpo da mulher e o corpo periférico são submetidos, mas, que também não deixa de ser um conjuro pela emancipação do desejo - seja amoroso, seja de movimento -, a começar pelo título, que afirma uma negação ao mundo que está posto.

À beira da crueldade do real, a poesia de Valeska Torres, em $O$ coice da égua (2019), dirige-se a uma cartografia poética atravessada pela política da morte, em diálogo 
com o conceito de necropolítica, cunhado por Achille Mbembe (2020). O filósofo camaronês identifica em países colonizados uma macroestrutura que opera regulando vida e morte, mediante o uso da força como uma política de "segurança", ou seja, constata-se o Estado atuando como possuidor de uma "licença para matar" em prol de um discurso de ordem - mais uma vez. Ocorre que, muitas vezes, os discursos utilizados para validar essas políticas resultam no reforço de preconceitos e marginalizações e, consequentemente, no extermínio de certos grupos.

Como no rap "Lei Áurea"18, de Borges MC - "Alguém me acorda desse pesadelo/ 111 tiros acertam um preto/ Menor jogado com corpo no beco/ Nossa pele faz nós já nascer suspeito/ Ágatha, Duda, Kauan, João Pedro/ E dizem que só quem morre é traficante/ Guerra licenciada pelo Estado/ Favela alimenta sua fome de sangue" -, no trecho do poema "O cupim comeu minha sorte", verifica-se a presença desse necropoder, ou seja, uma lógica da letalidade, exercida pela força policial, pela milícia etc., em que pessoas são confundidas com pragas:

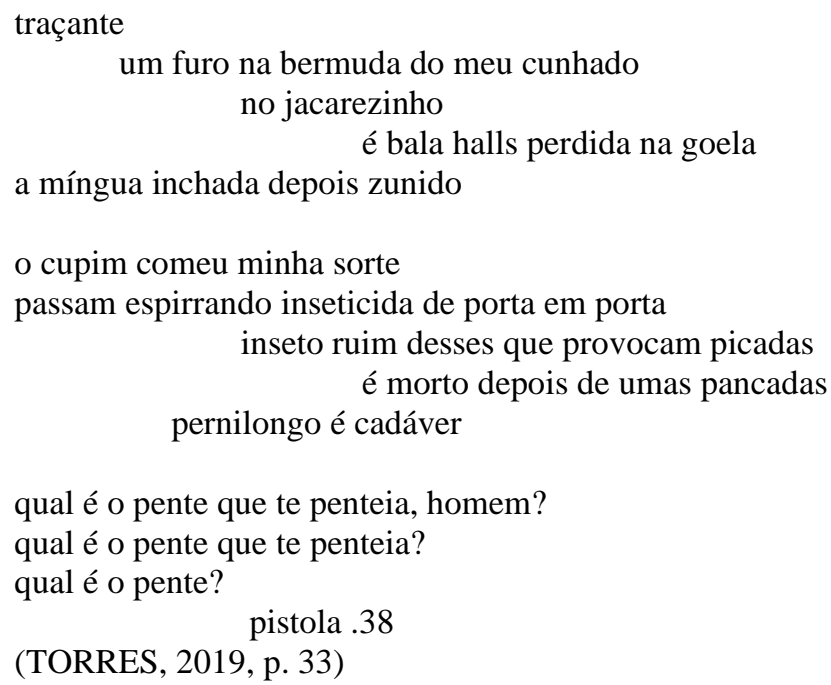

É proveitoso citar, por último, a obra do artista Elilson, cujos trabalhos nas ruas investigam as inter-relações entre performance e mobilidade urbana. Aproximando-se de uma tradição caminhante que alude às proposições dos situacionistas - do delirium ambulatorium, de Hélio Oiticica, da transurbância de Francesco Careri ${ }^{19}$, entre outros -, sua produção se interessa pela concidadania e se dedica a pensar o planejamento urbano, com iniciativas poéticas e políticas que se voltam à pratica da circulação na cidade, 
através da experimentação dos transportes coletivos e espaços públicos como espaços performativos.

Em "Troncal, uma palestra sobre a palavra no Rio de Janeiro"20, o pernambucano elabora uma fala acerca da origem etimológica do termo utilizado para nomear, a partir de 2015, as linhas de ônibus que foram implementadas em decorrência da extinção de outras 50, como parte do projeto urbanístico dos Jogos Olímpicos Rio 2016. Como quem responde ao poema de Valeska Torres, cujo título é "Que merda é essa de troncal?", com o uso de régua, flipchart, cartazes e traje social, Elilson percorre calçadas, estações e corredores de ônibus e metrô, colocando em suspeição o plano de racionalização do prefeito Eduardo Paes (grifo meu). Segue um trecho da palestra:

\begin{abstract}
Como um projeto de radical racionalização, o Troncal vem ganhando força nas ruas do Rio de Janeiro, de modo que passa a modificar outras palavras. Os verbos ocultar e camuflar, por exemplo, vão, modificados pelo uso, ganhando as formas de ocultal e camuflal. Vou explicar o porquê: o Troncal, hoje a entidade de maior destaque no transporte coletivo carioca, existe para ocultal ou camuflal - como vocês preferirem - o sumiço de algumas desaparecidas desta cidade. Neste momento, agradecendo a presença e a escuta dos senhores e senhoras e quebrando um pouco a formalidade de meu trabalho, gostaria que fizéssemos um minuto de silêncio por essas desaparecidas, as quais faço questão de nomear: [...] 157, 161, 162, 170, 172, 173,177, 178, 180, 183, 184, 190 (não é a polícia) [...] ufal! Mais de cinquenta linhas de ônibus desaparecidas e trocadas, muitas delas, pelo troncal. Ou seja, todos nós, nesta cidade, mandados para o troncal. Trata-se de um troncal cinquental, nesta cidade tropical! (ELILSON, 2017, p. 45)
\end{abstract}

Outras ações intrigantes do performer são "Bando recíproco" e "Escrita de vagão"; a primeira consiste em uma caminhada, junto a um grupo convidado, com espelhos em punho que formam composições típicas de protestos, requerendo uma dinâmica de jogo com a palavra reciprocidade, que é uma das propriedades fundamentais dos espelhos; a segunda se baseava em acompanhar o caminho de desconhecidos em estações e vagões de metrô, deixando que estímulos, do artista e dos passantes, coordenassem o tempo e a trajetória do trabalho. Ambos os percursos foram registrados em textos e fotos.

Essas proposições de Elilson se assemelham com jogos de detetive, na medida que buscam situações lúdicas que podem existir dentro das cidades, fazendo eclodir a cidade nômade que se esconde dentro da cidade sedentária. Seria como criar "espaços opacos", no dizer de Milton Santos, que se opõem aos espaços de luminosidade - tão abundantes 
em um mundo de hiperexposição, saturado -, fechados na exatidão, "racionalizados e racionalizadores" (JACQUES in CARERI, 2013, p. 13). Guilherme Wisnik (2018) também aponta a prevalência do nublamento nas obras da contemporaneidade, que se apresentam esfumadas e translúcidas, em detrimento da transparência, representada pelo vidro, índice da pureza e do esclarecimento racional moderno ${ }^{21}$.

É possível sustentar que o artista trabalha produzindo essas oportunidades de nublamento, em que se abrem brechas para a proximidade e para o que é turvo e impuro; foi o que pensei ao ler alguns registros de suas ações em uma rede social, como em "Bando recíproco", mais especificamente na primeira experimentação, realizada em 2016, em um protesto do \#VemPraRua, convocado pelo MBL:

\begin{abstract}
A presença dos corpos com os espelhos provocou reações e conversas diversas: houve quem se sentiu ofendido ao se ver, quem elogiou o uso dos espelhos verbalizando que "somos todos palhaços", quem partilhou memórias sobre o regime militar e também quem, pedindo a volta de uma intervenção militar, esbravejasse ao grupo que eles eram "comunistas que deveriam ser eliminados do país". O Bando, que também caminhou se olhando nos espelhos, mantevese recíproco às diversas abordagens, refratando as perguntas em novas perguntas, num fluxo contínuo de reflexão (ELILSON, 2016).
\end{abstract}

E em "Escrita de vagão":

O vagão está lotado, quase não dá para escrever. [...] Estou cansado. Estou imprensado. Estou frustrado. Não dá para sair pelo vagão catando o careca. Desisto e estou me questionando por desistir. O trem arranca. Passa um menino, não sei como, vendendo kit kat. Deve ter uns oito anos. Tem os pés e as sandálias havaianas encardidos. Se ele consegue passar eu também consigo, vou atrás dele. É a frase que eu penso. Não vou. Estou me prendendo. Estou imobilizado em movimento. Bem perto dos meus olhos, segurando firmemente o ferro, há uma mão negra, saliente e brilhante de mulher, com anéis e esmalte vermelho nas unhas. Lembro da mão de Elza Soares, mão que já beijei algumas vezes na vida. Parece exatamente com a dessa mulher. O menino vai e volta vendendo, dá um empurrãozinho de leve nas costas para poder passar. Estou rindo, admirando sua ousadia, mas meu olhar também tem tristeza. Olho para ele, olho para as mãos da mulher. Muitas vezes e sem parar. Tenho dúvida sobre o que me chama mais atenção. Fico turvo (ELILSON, 2020).

\title{
CONSIDERAÇÕES FINAIS
}

"Organizar o quê? Tá tudo organizado. O senhor que vê á'" 22 -, teria dito Pixinguinha a Isaac Frankel quando este pediu que o músico organizasse um conjunto para tocar na sala de espera do sofisticado Cine Palais. Assim nasceu o grupo Oito 
Batutas, em 1919. Se pensamos na trajetória dos cordões, banidos das ruas no início do século por serem considerados "sujos, grotescos e violentos", sendo aceitos apenas em sua versão comprometida "com uma adequada pureza nacionalista", proposta por Villa Lobos, em 1940 (NETO, 2017, p. 13-14); ou na já mencionada Festa da Penha, um dos berços do samba, onde gingavam os capoeiristas, rodavam-se os tabuleiros das tias e se celebravam todos os santos - o confronto entre ordem e desordem insiste, de alguma maneira, como em todas as obras elencadas aqui.

Nesse contexto, a fala de Pixinguinha acompanha (ou responde a) todas essas histórias até aqui. Parece-me que esse componente "desordeiro" - muito próprio do que é da rua -, que persegue boa parte das expressões culturais e produções artísticas no Rio de Janeiro, é um caráter atribuído por um olhar estrangeiro, alheio às gramáticas que são matutadas dentro dos desconcertos. Dessa forma, como propôs Mônica Velloso, ao eleger o humor como alicerce de seu estudo sobre a modernidade carioca, há que se reputar o comparecimento de uma visão anárquica da realidade como uma espécie muito peculiar de ordem, que se faz presente na expansividade, na atração pelo avesso e na vocação de estar junto.

Trata-se de um ordenamento que pode ser encontrado nas crônicas "A carroça dos cachorros”, de Lima Barreto, de 1919, e “Que gente é essa?”, de Luiz Antonio Simas, que narram as mobilizações das pessoas nas ruas, especialmente das mulheres pobres, em defesa dos cães ameaçados pela guarda municipal. Ou, ainda, no protesto de foliões, no Carnaval de 1904, em que se fez circular o panfleto com os seguintes versos:

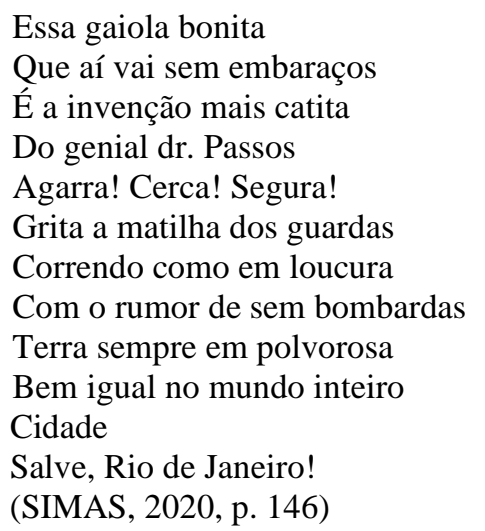

Segundo Simas, essa teria sido uma das primeiras vezes em que a alcunha "Cidade Maravilhosa" teria sido veiculada, quase uma década antes da poeta francesa se encantar 
pela metrópole. Olegário Mariano, em 1922, também chegou a publicar um livro chamado Cidade Maravilhosa, em que apelida o Rio de Janeiro de "cidade do amor e da loucura" (SIMAS, 2019, p. 146). Parece-me que essas concepções, antitéticas e porosas, permitiam a existência da rua que foi capaz de comover Barreto, sendo este um autor tão pouco afeito ao otimismo e com tantos motivos (e disposição) para maldizer a humanidade.

Essa é a rua que se oferece, afinal, como terreno profícuo em que brechas são abertas, por onde escorre o que não é compreendido pelos padrões normativos. É o terreiro de encontros impossíveis, que se apresenta como cenário onde se maquinam (e se insiste em) outros modos de conviver. Se "não existe redenção para as grandes tragédias, mas a vingança sublime e a única forma de transcendência dos homens ao desmazelo da vida é transformar a má fortuna e a dor em beleza, civilização e arte" (SIMAS, 2013, p. 17) - e é inevitável pensar que o convite de Isaac Frankel a Pixinguinha se deu após a aterradora epidemia de gripe espanhola -, é na ordem do olho da rua que a vida se reencanta e que o fazer artístico se converte em um tipo muito curioso de patuá contra a desventura. É na rua que se caminha, junto, entre o horror e o júbilo.

\section{Referências}

BARBOSA, Orestes. Bambambã. Disponível em: https://tonaniblog.files.wordpress.com/2016/05/bambambc3a3.pdf. Acesso em 20 mai. 2021.

BARRETO, Lima. "A carroça dos cachorros": Disponível em: http://www.biblio.com.br/defaultz.asp?link=http://www.biblio.com.br/conteudo/LimaB arreto/cronicas/acarrocadoscachorros.htm. Acesso em: 20 mai. 2021.

"De Cascadura ao Garnier": Disponível em: http://www.dominiopublico.gov.br/download/texto/bv000154.pdf. Acesso 20 mai. 2021.

“O cedro de Teresópolis". Disponível em: http://www.biblio.com.br/defaultz.asp?link=http://www.biblio.com.br/conteudo/LimaB arreto/cronicas/ocedrodeteresopolis.htm. Acesso em 10 ago. 2021.

Disponível

Os Bruzundangas. Editor Jacinto Ribeiro dos Santos. Rio de Janeiro, 1922.

https://digital.bbm.usp.br/bitstream/bbm/4801/1/001174 COMPLETO.pdf. Acesso em: 20 mai. 2021. 
- "Os enterros de Inhaúma". Disponível em: http://www.biblio.com.br/defaultz.asp?link=http://www.biblio.com.br/conteudo/LimaB arreto/cronicas/osenterrosdeinhauma.htm. Acesso em: 20 mai. 2021.

Triste Fim de Policarpo Quaresma. Revista dos Tribunais. Rio de Janeiro, 1915.

Disponível

em: https://digital.bbm.usp.br/view/?45000019930\&bbm/4361\#page/4/mode/2up. Acesso em: 20 mai. 2021.

BARRETO, Lima. Vida e morte de M. J. Gonzaga de Sá. Edição da Revista do Brasil São Paulo, $1919 . \quad$ Disponível em: https://digital.bbm.usp.br/bitstream/bbm/4800/1/001232_COMPLETO.pdf. Acesso em: 20 mai. 2021.

BENJAMIN, Walter. Passagens. Belo Horizonte: Editora UFMG, 2018.

CARERI, Francesco. Walkscapes: o caminhar como prática estética. Prefácio: Paola Berenstein Jacques. Tradução: Frederico Bonaldo. São Paulo: Editora G. Gilli, 2013.

ELILSON. "Bando recíproco". Disponível em: https://galeriavermelho.com.br/sites/default/files/artistas/pdf_portfolio/Elilson\%20_0.pd f. Acesso 20 mai. 2021.

ELILSON. "Bando recíproco": Disponível em: https://www.facebook.com/OcupaMincRJ/posts/67760907577770. Acesso em: 20 mai. 2021.

ELILSON. "Escrita de vagão", revista Garupa. Disponível em: http://revistagarupa.com/edicao/sentinela/secao/escrita-de-vagao/. Acesso em: 20 mai. 2021.

ELILSON. Por uma mobilidade performativa. Rio de Janeiro: Editora Temporária, 2017.

FARIAS, Juliana Barreto. "João do Rio e os africanos: raça e ciência nas crônicas da belle époque carioca”. In: Revista de História 162 (1ºmestre de 2010), p. 243-270 - USP, São Paulo, 2010.

FIGUEIREDO, Carmem Lúcia Negreiros de. "Paisagem e experiência urbana". Revista de Letras (Fortaleza), v. 1, n. 34, p. 65-77, 2015. Disponível em: http://www.periodicos.ufc.br/revletras/article/view/2405/1866. Acesso em 10 ago. 2021.

GOMES, Renato Cordeio. Todas as cidades, a cidade: literatura e experiência urbana. Rio de janeiro: Editora Rocco, 1994.

LACERDA. Izomar. "Nós somos batutas: uma antropologia da trajetória do grupo musical carioca Os Oito Batutas e suas articulações com o pensamento musical brasileiro". Disponível em: https://issuu.com/marcelooreilly/docs/0869-izomarlacerda. Acesso em: 20 mai. 2021. 
MBEMBE, Achille. "Necropolítica: biopoder soberania estado de exceção política da morte", Revista Arte e ensaios, UFRJ, v. 26, n. 40 (2020). Disponível em: https://revistas.ufrj.br/index.php/ae/article/view/8993/7169. Acesso em: 20 mai. 2021.

MEDEIROS, Gutemberg. "Teatralidade do espaço no fotojornalismo brasileiro: cidade e apagamento de papéis sociais na Primeira República" VII Simpósio Nacional de História Cultural. HISTÓRIA CULTURAL: ESCRITAS, CIRCULAÇÃO, LEITURAS E RECEPÇÕES. USP - São Paulo, 2014.

MEDEIROS, Juliane Porto Cruz de. "Ler a cidade: o Rio de Janeiro na obra de Lima Barreto". Universidade de Brasília Faculdade de Arquitetura e Urbanismo Programa de Pós-Graduação. $\quad$ Brasília, 2020.20 Disponível https://repositorio.unb.br/handle/10482/38931. Acesso em: 20 mai. 2021.

MITRANO, Bruna. Não. São Paulo: Editora Patuá, 2016.

NETO, Lira. Uma história do samba: as origens. São Paulo: Companhia das Letras, 2017.

PIRES, Paulo Roberto. "Elefantes entre cristais", revista Quatro cinco um, 11/2020. Disponível em: https://www.quatrocincoum.com.br/br/colunas/critica-cultural/elefantesentre-cristais. Acesso em: 20 mai. 2021.

RIO, João do. A alma encantadora das ruas. Organização Raúl Antelo. São Paulo: Companhia das Letras, 1997.

SCHWARCZ, Lilia Moritz. Lima Barreto: triste visionário. São Paulo: Companhia das Letras, 2017.

SIMAS, Luiz Antonio Simas. "A Penha no centro do mundo". Jornal O Globo, 12/10/2017. Disponível em: https://oglobo.globo.com/cultura/a-penha-no-centro-domundo-21938867. Acesso em: 20 mai. 2021.

SIMAS, Luiz Antonio Simas. O corpo encantado das ruas. Rio de janeiro: Editora José Olympio, 2020.

SIMAS, Luiz Antonio Simas. Pedrinhas miudinhas: Ensaios sobre ruas, aldeias e terreiros. Rio de Janeiro: Mórula editorial, 2013.

SOLNIT, Rebecca. A história do caminhar. Tradução Maria do Carmo Zanini. São Paulo: Martins Fontes, 2016.

TORRES, Valeska. O coice da égua. Rio de Janeiro: Editora 7Letras, 2019.

VELloso, Mônica Pimenta. A cultura das ruas no Rio de Janeiro (1900-1930): mediações linguagens e espaço. Rio de Janeiro: Edições Casa de Rui Barbosa, 2004. 
VELLOSO, Mônica Pimenta. "A mulata, o papagaio e a francesa, o jogo dos estereótipos culturais". In: LUSTOSA, Isabel. Imprensa, humor e caricatura, a questão dos estereótipos culturais, pp. 365-390. Belo Horizonte: UFMG, 2011.

VELLOSO, Mônica Pimenta. Modernismo no Rio de Janeiro: turunas e quixotes. Petrópolis: KBR Editora Digital Ltda., 2015.

WISNIK, Guilherme. Dentro do nevoeiro: arquitetura, arte e tecnologia contemporâneas. São Paulo: Ubu Editora, 2018.

Recebido em: 25/05/2021

Aceito em: 30/08/2021

\footnotetext{
${ }^{1}$ A questão dos estereótipos culturais e o conflito entre cidades foram abordados por Velloso em "A mulata, o papagaio e a francesa, o jogo dos estereótipos culturais". In: LUSTOSA, Isabel. Imprensa, humor $e$ caricatura. A questão dos estereótipos culturais. Belo Horizonte: UFMG, 2011.
}

2 "Feitiço da Vila". Disponível em: <https://www.vagalume.com.br/noel-rosa/feitico-da-vila.html $>$. Acesso em: 20 mai. 2021.

${ }^{3}$ Essas duas matrizes imaginárias da nacionalidade se complementavam: São Paulo, representada como uma manifestação apolínea, era possuidora do dom da ordem e organizava a turba de imigrantes que aportava em profusão na cidade sob o mito fundador do bandeirante; já o Rio de Janeiro era compreendido como uma figuração dionisíaca, caracterizando-se pelo "princípio do excesso e da desordem social", supostamente guardava sua capacidade mobilizadora para as celebrações (VELLOSO, 2015, p. 25-26).

4 “Nomes de favela". Disponível em: <https://www.vagalume.com.br/paulo-cesar-pinheiro/nomes-defavela.html>. Acesso em: 20 mai. 2021.

${ }^{5}$ Em "Flâneur", Benjamin cita Gustave Claudin, enumerando episódios banais, como quando um filé passa a ser chamado de chateaubriand: “'[...] nesse dia Paris perdeu definitivamente a coroa!' Jules Claretie, $L a$ vie à Paris 1896, Paris, 1897, p. 100” (BENJAMIN, 2018, pág. 711). Em “A rua”, João do Rio afirma: “A rua é a transformadora das línguas; Os Cândido de Figueiredo do universo estafam-se em juntar regrinhas para enclausurar expressões; os prosadores bradam contra os Cândido. A rua continua matando substantivos, transformando a significação dos termos, impondo aos dicionários as palavras que inventa, criando o calão que é o patrimônio clássico dos léxicos futuros" (RIO, 1997, pág. 47-48).

6 “Festa da Penha". Disponível em: <https://www.ouvirmusica.com.br/cartola/95700/>. Acesso em: 20 mai. 2021.

${ }^{7}$ Em “João do Rio e os africanos: raça e ciência nas crônicas da belle époque carioca”, Juliana Farias relata que as informações sobre as práticas de matriz africana veiculadas em suas crônicas, comparadas a relatos recentes, apresentam enganos e informações duvidosas, bem como preconceitos da sociedade branca da época. Disponível em: <https://www.revistas.usp.br/revhistoria/article/view/19158>. Acesso em: 20 mai. 2021.

${ }^{8}$ No texto flâneur: "O flâneur é o observador do mercado. Seu saber está próximo da ciência oculta da conjuntura. Ele é o espião que o capitalismo envia ao reino do consumidor” (BENJAMIN, 2018, pág. 717).

9 A menção de Süssekind se refere ao romance A Profissão de Jacques Pedreira, de João do Rio. SÜSSEKIND in RIO, João do Rio. A Profissão de Jacques Pedreira. São Paulo: Scípione/ Instituto Moreira Salles/ Fundação Casa de Rui Barbosa, 1992. 
10 “A favela vai abaixo". Disponível em: https://www.letras.mus.br/sinho/389472/. Acesso em: 20 mai. 2021.

${ }^{11}$ Sobre Machado de Assis, Lima Barreto tinha uma postura ambígua. Em sua Limana, estava toda a obra do referido autor, no entanto, Barreto não estava de acordo com o seu projeto literário, além de questionar a instituição da qual este era representante (ABL). Contudo, contestar Machado era também reconhecer a sua centralidade (Schwarcz, 2017, p. 139). Gomes afirma que o sobrenome do narrador de Vida e morte de M. J. Gonzaga de Sá foi uma "homenagem disfarçada" ao autor de Helena (GOMES, 1994, p. 156).

${ }^{12}$ Em Dom Casmurro, o protagonista pretendia escrever algo de utilidade para as gerações seguintes, "uma História dos subúrbios", mas acaba engavetando o projeto. É interessante lembrar que Bentinho evoca as figuras de César, Augusto e Nero, ditadores militares que, favorecidos pelo declínio da República romana, estabeleceram o Império. Casmurro parece acompanhar a reordenação do espaço urbano, em suas mudanças de residência, seguindo a rota de expansão do subúrbio (SCHWARCZ, p. 164-165).

${ }^{13}$ Lima Barreto esteve no coração pulsante da cidade e entendia a importância da relação entre modernidade e vida urbana. Contudo, encara com desconfiança o cosmopolitismo identificado com o modelo parisiense, bem como percebe a perda da experiência ligada às formas culturais tradicionais (GOMES, 1994, p. 106).

${ }^{14}$ Simas produziu uma trilogia das ruas em Pedrinhas miudinhas: Ensaios sobre ruas, aldeias e terreiros (2013), O corpo encantado das ruas (2019) e Arruaças: uma filosofia popular brasileira (2020), com coautorias de Luiz Rufino e Rafael Haddock-Lobo.

${ }^{15}$ Por uma questão de limitação de tamanho do artigo, não pude trabalhar com outras autoras que também têm a rua como eixo temático, como Tatiana Pequeno, Maria Isabel Iorio, entre outras.

${ }^{16} \mathrm{O}$ poema foi publicado na Revista Alĕre, mas não consegui visualizar. No momento, disponível em: https://www.youtube.com/watch?v=YyHf4hOn31U. Acesso em: 20 mai. 2021.

17 "Moro lá". Disponível em: https://www.letras.mus.br/renato-da-rocinha/moro-la/. Acesso em: 20 mai. 2021.

18 "Lei Áurea". Disponível em: https://www.vagalume.com.br/borges-mc/lei-aurea.html. Acesso em: 20 mai. 2021.

${ }^{19}$ Walkscapes, de Careri, traça uma genealogia do caminhar, desde o nomadismo primitivo às vanguardas artísticas. Comparo o trabalho de Elilson aos situacionistas e ao grupo de Stalker pela convergência no gosto pela investigação da cidade e pela sensibilidade às transformações da contemporaneidade enquanto sintomas de uma sociedade em mutação (ou decomposição) (TIBERGHIEN in CARERI, 2013, p. 17). Em Oiticica, a errância também era primordial: ele tinha o hábito de atravessar o subúrbio de ônibus, de um ponto final ao outro, só para ver onde dava. Os passeios a pé pelo Morro na Mangueira, por áreas marginalizadas, como a região do Mangue, foram fundamentais em sua produção artística (JACQUES in CARERI, 2013, p. 9).

20 "Troncal, uma palestra sobre a palavra no Rio de Janeiro". Disponível em: https://www.youtube.com/watch?v=w-Wy1p-zz1c\&ab_channel=Elilson. Acesso em: 20 mai. 2021.

${ }^{21}$ Um dos exemplos anti-iluministas é "A noiva despida por seus celibatários, mesmo" (1915-23) ou "O grande vidro", misto de pintura mural e peça ambiental, é uma obra de dimensão crítica e turva, que incorporou os sulcos e a poeira impregnada em sua constituição. Octavio Paz aponta nesse trabalho de Duchamp um contraponto à vertigem da aceleração moderna em uma "vertigem do retardamento" (WISNICK, 2018, p. 17)

${ }^{22}$ Depoimento gravado em áudio, encontrado no Museu da Imagem e do Som, segundo Izomar Lacerda. 